\title{
Detrital zircon provenance and Ordovician terrane amalgamation, western Ireland
}

\author{
Brian McConnell, Geological Survey of Ireland, Beggars Bush, Dublin 4, Ireland, \\ brian.mcconnell@gsi.ie \\ Nancy Riggs, Department of Geology, Northern Arizona University, Flagstaff, AZ \\ 86011 USA \\ Quentin G. Crowley, NERC Isotope Geosciences Laboratory, Kingsley Dunham Centre, \\ Nottingham NG12 5GG, UK \\ Current address: Department of Geology, Trinity College, Dublin 2, Ireland \\ 5300 words, 45 references, 2 tables, 11 figures \\ Running title: Detrital zircon provenance, western Ireland
}

\begin{abstract}
Detrital-zircon analysis of sandstones interbedded with ca $464 \mathrm{Ma}$ ignimbrites in the lower Mweelrea Formation of the South Mayo Trough, western Ireland, suggests Ordovician source-rock provenance that corresponds to two distinct volcanic-arc phases on the Laurentian margin. East-derived sandstones contain a suite of zircons with a mean age of ca 487 Ma that suggests derivation from the Cambrian to early Ordovician Baie Verte Oceanic Tract arc/ophiolite complex, locally represented by the Lough Nafooey arc rocks and the Clew Bay Complex. Zircons from south-derived sandstones within the Bunnacunneen conglomerate fan have average ages of ca $467-474 \mathrm{Ma}$, and correspond to the Notre Dame arc and locally the Connemara metagabbro and orthogneiss suite. Granite clasts in the Bunnacunneen conglomerate are similar to the Connemara orthogneiss suite, both in terms of their geochemistry and age (ca $471 \mathrm{Ma}$ ). The southerly derived sedimentary strata also include Archaean and Proterozoic zircon age spectra consistent with a Dalradian source. A southern provenance from the Notre Dame arc and Dalradian suggests that the Connemara terrane lay to the south of the South Mayo Trough during middle Llanvirn times, from at least 464 Ma.

Supplementary material: U-Pb LA-MC-ICPMS data for detrital zircons and details of analytical methods for U-Pb LA-MC-ICPMS and U-Pb ID-TIMS analyses are available at http://www.geolsoc.org.uk/SUP00000.

The Caledonian - Appalachian orogen in eastern North America, Ireland and Britain is a complex mosaic of terranes and has been inferred to represent the collision of westernPacific-type tectonic elements (van Staal et al. 1998). Within such large-scale orogens, local geological histories will vary, due, for example, to the presence of microcontinents or to diachronous collisions. The first-order sequence of events, however, should conform to the large-scale plate dynamics of the margin.
\end{abstract}


Successions preserved in eastern North America indicate that Cambrian to early Ordovician oceanic volcanic arcs and supra-subduction ophiolites were obducted and accreted onto Laurentia (Baie Verte Oceanic Tract), followed by subduction-polarity flip and development of the $488 \mathrm{Ma}$ to 456 Ma Notre Dame magmatic arc within the Laurentian accretionary margin (van Staal et al. 1998 and references therein). A similar history of successive Ordovician magmatic arcs is evident in western Ireland (Ryan and Dewey 1991, Dewey 2005). Early Ordovician, oceanward-directed subduction formed the Lough Nafooey oceanic volcanic arc (Figs 1, 3; Clift and Ryan 1994, Chew et al. 2007); this arc and the associated South Mayo Trough fore-arc basin collided with the Laurentian margin from approximately $475 \mathrm{Ma}$, causing the Grampian (Taconic) orogeny (Soper et al. 1999, Dewey 2005). A change in subduction polarity then produced ca 475462 Ma magmatic arc intrusions within the Neoproterozoic metasedimentary sequence (Dalradian) of the deforming Laurentian margin (Friedrich et al. 1999a, Leake 1989).

Connemara is a piece of Dalradian Laurentian crust that now lies to the south of the obducted-accreted Lough Nafooey arc terrane and South Mayo Trough (Fig. 1). The relative position of Connemara during sedimentation in the South Mayo Trough is crucial to understanding the development and paleogeography of the margin. The emplacement of Connemara adjacent to the Lough Nafooey arc terrane is an important episode in the Grampian Orogeny, but the timing and mechanism of that emplacement are unresolved. Although there is evidence that it occurred before deposition of the late Ordovician or early Silurian Derryveeny conglomerate (Graham et al. 1991; Fig. 3), the earliest contribution of Connemara to sedimentary successions along the Laurentian margin has not previously been constrained.

The South Mayo Trough sedimentary basin (Figs 1, 2, 3) occupied a key position in this history. Its 8 km thick fill (Pudsey 1984a) preserves Arenig to early Llanvirn (ca 478$464 \mathrm{Ma}$ ) turbidites that provide evidence of unroofing of ophiolitic and Dalradian rocks to the north (Wrafter and Graham 1989, Dewey and Mange 1999). These turbiditic successions are overlain by Llanvirn to Caradoc (ca 464-460 Ma) fluvial to shallow marine sandstones of the Mweelrea Formation, which record volcanic arc and metamorphic source areas (Dewey and Mange 1999). Paleocurrents predominantly indicate east-derived flow (Pudsey 1984b), but the formation also contains a southerly derived alluvial fan facies that has been overlooked as a source of important data in the evolving history of terrane amalgamation of this section of the Laurentian margin.

In this paper we present the results of a study of Ordovician rocks in the South Mayo Trough that combines detrital-zircon analysis with conglomerate-clast petrology and geochemistry, building on an established geological base (e.g., Pudsey, 1984a, b; Graham et al., 1991). Strata of the Mweelrea Formation contain detrital zircons and conglomerates that provide evidence of the earliest amalgmation of the Connemara block with the South Mayo Trough. Our results strongly suggest that the Connemara block was in a position to the south of the South Mayo Trough by Mweelrea (middle Llanvirn, ca $464 \mathrm{Ma}$ ) time and that the uplifting and eroding Connemara block provided primary volcanic material (ignimbrites), deeper magmatic arc rocks (granite clasts) and Dalradian 
metasedimentary detritus. Our new data provide a clearer picture of the similarities between disparate parts of the margin and further illucidate the palaeogeographic relations within the Caladonian - Appalachian orogen now exposed in western Ireland and northeastern North America.

\section{Regional geology}

The Ordovician rocks of South Mayo were folded into a large synclinorium before late Llandovery deposition of unconformable Silurian sedimentary sequences, and the north and south limbs preserve different aspects of pre-Mweelrea Formation geological history. To the south, the Lough Nafooey Group and Tourmakeady Volcanic Succession (Figs 2, 3) record magmatism in a north-facing, peri-Laurentian volcanic arc (Clift and Ryan 1994). To the north of the arc, the South Mayo Trough continued to be filled during obduction of the oceanic plate and its accretionary complex (preserved as elements of the Clew Bay Complex, Fig. 1) northward onto the Laurentian margin (Ryan and Dewey 1991). The obduction event caused early Grampian (Taconic) deformation and metamorphism of the Laurentian-marginal Dalradian Supergroup (Soper et al. 1999, Dewey 2005).

A $6 \mathrm{~km}$ thick succession of Arenig to mid-Llanvirn (ca 478-464 Ma) turbidites exposed on the north limb of the syncline preserves the signature of this history (Dewey and Mange 1999) with a change in sediment provenance in northerly derived detritus from mafic to ophiolitic to metamorphic during unroofing of the obducting ophiolite and the underlying Dalradian metasedimentary rocks. Ophiolitic detritus in the upper Arenig Sheeffry Formation (Fig. 2) has a serpentine-rich mineralogy and abundant chrome spinel, and the rocks are talcose and fuchsitic in shear zones north of Doolough (Fig. 3). Alluvial plain to delta sandstones of the Mweelrea Formation form the $2 \mathrm{~km}$ thick top of the preserved stratigraphy.

During obduction of the oceanic plate, a subduction-polarity reversal produced a largely ensialic, south-facing magmatic arc within the deforming margin (Ryan and Dewey 1991, van Staal et al. 1998, Friedrich et al. 1999a,b). The intrusive syntectonic metagabbros and orthogneisses of the Connemara Metagabbro and Gneiss Complex (Leake 1989) within the Connemara Dalradian represent the root zone of this arc. Arc magmatism occurred mainly during the D2 and D3 (Arenig-Llanvirn) phases of the Grampian orogeny (ca 475-462 Ma), though the latest granitic components such as the Oughterard Granite (462.5 \pm 1.2 Ma; Fig. 1) are undeformed (Friedrich et al. 1999a). The metagabbro had an initial tholeiitic to high-alumina basalt composition, while the orthogneiss protoliths crystallized from a genetically related calc-alkaline dioritic to granodioritic magma, initially producing hornblendic quartz diorite and progressing to lesser volumes of granite.

The Connemara Dalradian block of Appin, Argyll, and Southern Highland group metasedimentary rocks (Long et al. 2006) is the only Dalradian crust to the south of the Fair Head-Clew Bay lineament (Fig. 1), the continuation of the Highland Boundary Fault that is considered to mark the southern margin of Laurentian crust. It has been generally believed that Connemara arrived in its outboard position to the south of the South Mayo 
Trough by post-460 Ma strike-slip terrane amalgamation, to provide a southern sediment source of metamorphic clasts for the late Ordovician or early Silurian Derryveeny

141 Formation (Hutton 1987, Graham et al. 1991). The Connemara block is the only part of 142 the Laurentian margin in western Ireland to be intruded by Notre Dame arc rocks, and 143 Notre Dame arc ignimbrite volcanism is preserved in the adjacent South Mayo Trough.

Silurian rocks unconformably overly and obscure the northern and southern margins of the South Mayo Trough so that contacts with the Connemara block and the Clew Bay Complex are not exposed. Timing of pre-Silurian folding of the South Mayo Trough sedimentary rocks, including the Mweelrea Formation, could be late Grampian or an otherwise unrecognized event occurring between the Grampian and Acadian orogenies. If Grampian, the $462.5 \pm 1.2$ Ma age of the late- to post-D4 Oughterard Granite (Friedrich et al.1999a) places a minimum age limit on the first folding of the South Mayo Ordovician rocks. Harper and Parkes (2000) have proposed a Caradoc age for faunas in the upper (Glenconnelly) slate member of the Mweelrea Formation, at the centre of the Mweelrea Syncline (Fig. 3). The base of the Caradoc is estimated at $460.9 \pm$ 1.6 Ma on the Gradstein et al. (2004) timescale, within error of the age determined for the Oughterard Granite. It therefore appears possible that late Grampian deformation initiated development of the Mweelrea Syncline but that deposition continued in the basin into the Caradoc as D4 deformation waned, or that onset of D4 folding was diachronous, being slightly later in South Mayo.

\section{The Mweelrea Formation}

The Mweelrea Formation (Figs 2, 3) consists predominantly of coarse, poorly sorted, cross-bedded sandstone and pebbly sandstone with local conglomerate. Palaeocurrent directions are unimodal from the east, southeast or south. Clasts are predominantly of undeformed granite, felsic volcanic and metamorphic rocks, and heavy mineral suites support a mixed volcanic arc and metamorphic terrain source area (Dewey and Mange 1999). Pudsey (1984b) and Williams (1984) interpreted the environment of deposition as an alluvial plain to fan delta prograding to the west. The formation reaches a preserved thickness of at least $2100 \mathrm{~m}$ in the centre of the Mweelrea Syncline. Three prominent slate horizons, lithologically similar to the underlying Glenummera Formation, record marine incursions into the generally shallowing basin (Figs 2, 3). The slate horizons have sharp bases, coarsen up into more typical Mweelrea Formation sandstones and show evidence of bioturbation and wave activity. Shallow marine faunas indicate early to middle Llanvirn ages for the lower two units (Stanton 1960, Williams 1972, Pudsey 1984a) and an early Caradoc age for the upper, Glenconnelly Member (Harper and Parkes 2000).

The Mweelrea Formation contains five (Stanton 1960) or six (Dewey 1963) laterally extensive ignimbrites that are separated by sandstone and are individually up to $20 \mathrm{~m}$ thick. They consist of flattened red pumice clasts, lithic lapilli, and broken feldspar and quartz crystals in a purple, non-welded matrix in which glass shard forms are commonly preserved. Stanton (1960) suggested that green bases to the ignimbrites in the west resulted from deposition in shallow water. The ignimbrites commonly have reworked 
tops overlain by conglomerate and magnetite-rich sandstone.

The age of the ignimbrites is constrained stratigraphically by artus and murchisoni biozone faunas (Llanvirn) in the underlying Glenummera Formation and overlying Glendavock slate member respectively (Fig. 2; Harper and Parkes 2000). U-Pb isotopic dating of the lowest ignimbrite (S. Noble in Dewey and Mange, 1999) provided an age of $464 \pm 4 \mathrm{Ma}$, which is consistent with the biostratigraphic Llanvirn age.

A local conglomerate sequence, the Bunnacunneen Conglomerate Member (Williams 1984), is exposed at the southern margin of the preserved Mweelrea Formation west of Lough Nafooey (Figs 3, 4). The member comprises several layers of clast-supported conglomerate with well-rounded clasts and thin intercalated lenses of sandstone and pebbly sandstone, interbedded with the lower three Mweelrea ignimbrites. Common clast types are non-foliated granitoids and quartz-porphyry, which make up the largest clast sizes (up to $90 \mathrm{~cm}$ across; Fig. 4), and foliated and non-foliated psammites. Less common clast types, rarely more than $10 \mathrm{~cm}$ in diameter, are vein quartz, schist, red chert and rare, small mafic igneous rock types. Williams (1984) recorded palaeocurrent directions from the southeast from clast imbrication in conglomerate and crosslamination in adjacent sandstone, and interpreted the member as an alluvial fan. Our investigations have not confirmed the presence of south-derived palaeocurrent indicators, but the occurrence of the very coarse sediment only on the southern edge of the preserved basin supports a southerly derivation of that material.

\section{Sampling strategy}

We determined U-Pb zircon ages of detrital zircons from sandstones of the Mweelrea Formation to compare the provenance of source rocks for the Bunnacunneen Conglomerate Member to those for sediment from the main sandstone sequence that shows generally easterly derived palaeocurrent directions. Four sandstone samples were collected, two from Bunnacunneen and one from Bundorragha on the south side of the Mweelrea syncline, and one from Derritin Lough on the north side of the syncline (Fig. 3). The Bundorragha sandstone sample was collected from near the base of the Mweelrea Formation, below the lowest basin-wide ignimbrite and close to the contact with the underlying Glenummera Formation, in what Pudsey (1984b) termed the “passage beds” [Irish Grid Reference L 8494 6300]. The Derrintin Lough sample came from the base of the Mweelrea Formation on the north side of the syncline, below the basal ignimbrite [L 9249 6696] in a stratigraphic position equivalent to the Bundorragha sample. The lower Bunnacunneen sample was obtained from sandstone just below the basal Mweelrea ignimbrite [L9488 5903], and the upper from a sandstone lens in conglomerate between the second and third ignimbrites [L 9463 5906]. Zicons separated from the sandstone samples display a variety of morphologies from well-rounded, to subhedral to euhedral and representative grains of each type were analysed. Inherited cores and magmatic melt inclusions were evident in some grains of all morphology types.

Granite clasts were sampled from the Bunnacunneen conglomerate for petrological and geochemical study. In addition, zircons from one of these clasts were analysed by 
Isotope Dilution Thermal Ionization Mass Spectrometry (ID-TIMS) for age correlation with potential sources (Fig. 3; 03/04b, Table 1).

\section{U-Pb zircon geochronology}

$\mathrm{U}-\mathrm{Pb}$ geochronology of detrital zircons was conducted by laser ablation multicollector inductively coupled plasma mass spectrometry (LA-MC-ICPMS) at the Arizona LaserChron Center (ALC), University of Arizona, USA and also at the NERC Isotope Geosciences Laboratory (NIGL), Nottingham, England. Zircons from the Bunnacunnen conglomerate granite clast were analysed by Isotope Dilution Thermal Ionization Mass Spectrometry (ID-TIMS) at NIGL. Full analytical protocols, applied data corrections and processing and plotting rationales, and data table for detrital zircon LA-MC-ICPMS analysis are given in the supplementary data file available at http://www.geolsoc.org.uk/SUP00000.

\section{Results}

Sedimentary rocks. Analysis of 113 zircon grains in total from the Bundorragha sandstone (03/230 and 07/102; Fig. 5) yields a main early Ordovician peak, with other minor peaks at ca 1000, 1500, 1900 and 2700-2800 Ma. Treating the Cambrian and Ordovician grains $(n=42)$ as a sub-set of the total population yields a high frequencyprobability and median TuffZirc age of ca 486 Ma. (Fig. 5A,B).

Analysis of 60 zircons from the Derrintin Lough sample (07/101, Fig. 6) shows a dominant early Ordovician peak (Fig. 6A; n=32), with a maximum at ca $486 \mathrm{Ma}$ and a TuffZirc median of ca $484+6 /-2$ Ma, the strongly assymetrical error likely due to the presence of some older inherited components (Fig. 6B).

Analysis of 113 grains from the lower Bunnacunneen sandstone (03/227, 07/104, Fig. 7) yields a dominant Middle Ordovician age component. A probability maximum between 465 and ca 470 Ma was calculated for the Cambrian-Ordovician group $(n=34$, Fig. 7B) using frequency-probability and TuffZirc functions respectively. Analysis of 83 grains from the upper Bunnacunneen sandstone (03/228, 07/103, Fig. 8) indicates a dominant latest early Ordovician peak (Fig 8A), with a Tuffzirc age of ca 474 for the CambrianOrdovician group and a probability maximum at ca $477 \mathrm{Ma}(\mathrm{n}=23$, Fig. 8B). Both Bunnacunnen samples have additional maxima at ca 1000-1100 Ma and ca 2700-2800 $\mathrm{Ma}$, and the lower sandstone has an additional minor probability peak at ca $1800 \mathrm{Ma}$ (Figs. 7, 8).

Granite clast. A total of seven single grain acicular or prismatic tip fractions were analysed by ID-TIMS, with between 7 and $80 \mathrm{pg}$ of radiogenic $\mathrm{Pb}$ for analysis. Four of these fractions are concordant and overlap within error [Z1, Z2, Z4, Z14] to produce a concordia age of $470.6 \pm 1.0 \mathrm{Ma}$ (concordance and equivalence MSWD $=2.4$, probability $=0.02$; Fig. 9) and a mean ${ }^{206} \mathrm{~Pb} /{ }^{238} \mathrm{U}$ age of $470.5 \pm 1.4 \mathrm{Ma}(\mathrm{MSWD}=6.6$, probability of fit $=0.03$ ). The relatively high MSWD and low probability of both these age calculations reflects a slight spread in the data, most likely to have resulted from some small amounts of $\mathrm{Pb}$-loss not totally removed by the chemical abrasion procedure. Three fractions [Z11, Z12, Z14] are discordant due to the presence of an inherited component. An attempted 
discordia between all seven fractions results in a high MSWD (not shown), probably indicating that more than one inherited age component is present.

\section{Interpretation of detrital-zircon data}

The detrital zircon signatures from Bundorragha, Derrintin Lough and Bunnacunneen sandstones are similar but do have important differences. The Cambro-Ordovician probability maximum in the Bundorragha and Derritin Lough samples is ca 486 Ma (Figs 5 , 6). Ages older than ca 475 Ma have not been recorded from any potential magmatic source rocks up palaeo-drainage to the north and east of the South Mayo Trough. The Arenig Lough Nafooey volcanic arc likely formed in the interval 470 - 500 Ma (Chew et al. 2007), but the arc formed, and the extant rocks lie, south of the South Mayo Trough. The >475 Ma zircon ages are equivalent in general to the Baie Verte Oceanic Tract along strike to the west in Newfoundland (Jenner et al. 1991, Dunning and Krogh 1985, Elliott et al. 1991, Cawood and van Gool 1998). The local Baie Verte-equivalent rocks were removed, probably by erosion during the previously recognised obduction onto the Laurentian margin. The Clew Bay Complex (Fig. 1) serpentinites and melange mark the suture of an obducted ophiolite that was the source of northerly derived mafic and ultramafic detritus in the lower part of the South Mayo Trough fill. The abundance of late Cambrian-early Ordovician zircons suggests that felsic intrusions like the Baie Verte trondhjemites and tonalities were present in the ophiolite. Plagiogranite clasts in the basal Silurian conglomerate unconformably overlying the South Mayo Trough sedimentary rocks, dated at ca $490 \mathrm{Ma}$ (Chew et al. 2007), were probably derived from a similar source.

Ordovician zircon ages from sandstones at Bunnacunneen are in general younger than those from Bundorragha and Derrintin Lough. Ordovician maxima for Bunnacunneen samples (Figs 7, 8) correspond with the age of ignimbrites in the Mweelrea Formation (ca $464 \mathrm{Ma}$, Dewey and Mange 1999), the age range of the Connemara magmatic arc (ca 475-463 Ma, Friedrich et al. 1999a), and the Notre Dame arc in general (van Staal et al. 1998). Another potential source of ca $460 \mathrm{Ma}$ to ca $475 \mathrm{Ma}$ grains is the granitic and tonalitic intrusions within the Slishwood Division to the east along the Laurentian margin (Fig. 1; Flowerdew et al. 2005), but given the apparent derivation of Bunnacunneen material from the south, a derivation of zircons from the Slishwood Division seems less likely. Since the lower Bunnacunneen sample came from below the first ignimbrite, the Notre Dame-age suggests an extra-basinal source for zircons in the sandstone. The observation that the upper Bunnacunneen sample has an older Ordovician maximum than the basal sample is considered to represent unroofing of the Connemara/Notre Dame arc and concomitant supply of material containing older zircons.

The Archaean and Proterozoic grains in all samples are consistent with a Laurentian source (Cawood et al. 2007). The Bunnacunneen samples (Figs. 7, 8) have relatively strong concentrations of grains at ca $2700-2800 \mathrm{Ma}$ and all samples have less pronounced probability peaks at ca $1000-1150 \mathrm{Ma}$. These age peaks are prominent in detrital-zircon age spectra from Dalradian metasedimentary rocks (Cawood et al. 2003) and, while not diagnostic, a Dalradian source is likely for the Archaean and Proterozoic zircons in the Mweelrea Formation, including those with southern provenance. First- 
cycle derivation of zircon from more distal Archaean and Grenville source areas is possible for the northerly and easterly sourced detritus, but such sources are not known to

\section{Bunnacunneen conglomerate clast petrology}

Nine granite clasts were selected for petrological and geochemical study (Table 2). Most of the samples fall within a petrographic group of similar mineralogy and texture. Within this group, plagioclase (24-34\%) has equant shapes, is albite-carlsbad twinned and is zoned with altered cores and relatively unaltered rims. Interstitial K-feldspar (24-36\%) is highly perthitic in some samples, less so in others. Exolved quartz blebs are also common in the perthitic samples. Altered biotite $(<4 \%)$ is the only mafic phase, and muscovite is rare. Some samples $(03 / 04,03 / 06,01 / 750)$ contain small, common to rare garnet; the small sample set suggests a correlation between the presence of garnet and well-developed feldspar exolution textures. Quartz (28-45\%) typically forms large glomerocrysts with complex internal surfaces. One sample (03/08) shows a bimodal size distribution of quartz crystals. One granite sample (03/02) is distinct from the others in containing uncommon blue pleochroic riebeckite as bladed, skeletal crystals, and diorite enclaves comprising an altered assemblage of amphibole, biotite, plagioclase and quartz.

Whole rock geochemical data were obtained for eight granitoid clasts from the Bunnacunneen conglomerate by XRF and ICP-OES at the University of Leicester (Table 2). The granitoid clasts in general are high- $\mathrm{SiO}_{2}$ (up to 82.7\%), low- to medium-K (Fig. 10a), peraluminous $(\mathrm{A} / \mathrm{CNK}=1.0-1.3)$ granites. They have high $\mathrm{Th} / \mathrm{Y}$ ratios and other trace element characteristics of volcanic arc granites (Fig. 10b) and plot in the Volcanic Arc Granite (VAG) field of the Rb v. Nb+Y discriminant plot of Pearce et al. (1984; Fig 10c). The garnetiferous granites have higher HREE and $Y$ concentrations and relatively lower LREE enrichment than the other varieties, resulting in concave REE profiles (Fig. 10d). The garnetiferous samples also have larger negative Eu anomalies and lower $\mathrm{Zr} / \mathrm{Nb}$ ratios.

\section{Source of the Bunnacunneen clasts}

The geochemical data suggest a Connemara source for the granite clasts at Bunnacunneen. High $\mathrm{SiO}_{2}$ content is a recognised feature of the granitic components of the Connemara metagabbro and orthogneiss suite (Leake 1989), to which the Bunnacunneen clasts also show trace element geochemical similarity (Fig. 10b,c). While the clasts have lower $\mathrm{Zr}$ content than the orthogneiss data of Leake (1989; Fig. 10b), Clift et al. (2003) reported very low $\mathrm{Zr}$ in the five orthogneiss samples they analysed. In addition, orthogneiss-suite samples plot in the VAG field (Fig. 10c) with Bunnacunneen clasts.

The Oughterard Granite, regarded as the final phase of the Connemara magmatic arc (Friedrich et al. 1999a), has a wide range of composition (Bradshaw et al. 1969), suggesting that multiple intrusions formed a composite pluton. The Connemara magmatic arc was intruded during the latter stages of the Grampian orogeny, so that the granitic magmas may progressively record syn-orogenic magmatism and multiple sources. The wide compositional spectrum and limited range of trace element data 
available for the Oughterard granite makes comparison with the Bunnacunneen clasts difficult, except to say that the Bunnacunneen clasts have a restricted, volcanic-arc

The $\mathrm{Rb}$ v. $\mathrm{Nb}+\mathrm{Y}$ discriminant plot (Fig. 10c) clearly distinguishes between Bunnacunneen granite clasts and granite clasts from the older Rosroe Formation. The latter are considered by Clift et al. (2003) on geochemical grounds to have been derived from Precambrian granites in the Laurentian margin, consistent with palaeocurrent evidence in Williams (2002). Previously, Archer (1977) had suggested a southern volcanic arc source, but the more recent evidence, including that presented here, indicates that the Rosroe granite clasts are not related to those in the Bunnacunneen conglomerate.

The U-Pb zircon age of granite clast 03/04b is $470.6 \pm 1.0 \mathrm{Ma}$, similar to the Friedrich et al. (1999a) age for the Cashel - Lough Wheelaun gabbro of Connemara and within their age range of ca 475 to $463 \mathrm{Ma}$ for the Connemara magmatic arc. The size of granitic clasts (up to $90 \mathrm{~cm}$ ) suggests that they were not far traveled, and the limited palaeocurrent evidence suggests derivation from the south.

The psammitic and semi-pelitic schist clasts in the Bunnacunneen conglomerate have a high greenschist facies metamorphic mineral assemblage typical of Dalradian metasedimentary rocks, such as the nearby Ben Levy Grit Formation of Connemara, although they are not diagnostic of any particular Dalradian area. They are of lower metamorphic grade than the quartzose metasedimentary rocks from the (?pre-Dalradian) Slishwood Division of the Ox Mountain inlier (Fig. 1) except where those rocks were retrogressed during the Grampian orogeny.

\section{Discussion}

Sedimentary strata of the lower Mweelrea Formation of the South Mayo Trough include two age-distinct Ordovician source rock components that correspond to different volcanic arc phases on the Laurentian margin; the Cambrian to early Ordovician Baie Verte Oceanic Tract arc/ophiolite complex to the north and the mid-Ordovician Notre Dame arc to the south. Both groups also include late Archaean and Proterozoic zircon age spectra that correlate with the Laurentian signature found in Dalradian metasedimentary rocks. The southern provenance from a terrain with Notre Dame arc and Laurentian signatures suggests that the Connemara terrane lay to the south of the South Mayo Trough during middle Ordovician times.

The U-Pb zircon age of $470.6 \pm 1.0 \mathrm{Ma}$, the geochemical similarity of the Bunnacunneen granite clasts to the Connemara granitic orthogneisses, and the southerly position of the orthogneisses and the likely southerly derivation of the clasts, suggests that rocks related to the orthogneiss suite were the source of the clasts. Although the orthogneisses are ubiquitously foliated while the granite clasts are not, we propose that the clasts were derived from a scarcely deformed high level in the eroding arc, while the currently exposed granitic orthogneisses are a deeper, more deformed level. Common quartz-porphyry clasts in the conglomerate were probably also derived from high-level hypabyssal intrusions in the arc. Whereas the currently exposed granitic gneisses in 
413 Connemara are associated with large volumes of metagabbro, mafic clasts in the 414 Bunnacunneen conglomerate are rare, small, highly altered and cannot be recognized as

415 from the metagabbro suite. This could be a further indication of a high-level clast source 416 but could also be due in part to the limited durability of mafic clasts during sediment 417 transport (Ufnar et al. 1995). In the latter regard it is notable that red chert clasts, 418 presumably derived from occurrences in the adjacent Lough Nafooey volcanic arc rocks, 419 are much more common in the conglomerate than mafic clasts that might have been

\section{Basin model: a southerly Connemara in the Llanvirn}

Our data indicate that the Connemara block was the source of the southerly derived Bunnacunneen fan conglomerates within the generally easterly derived Mweelrea Formation. We propose that Connemara lay to the south of the South Mayo Trough from about $464 \mathrm{Ma}$, significantly earlier than deposition of the late Ordovician or early Silurian Derryveeny Formation, previously the earliest recognized evidence for a southern Connemara source (Graham et al. 1991). The commonality of D2 (early Arenig) deformation and metamorphism in Connemara, North Mayo and the Ox Mountains Dalradian (Long et al. 2006) appears to require that Connemara was subject to the early Grampian/Taconic obduction event. Subsequent to this, Connemara became the locus of intrusion of a magmatic arc above north-directed subduction, although North Mayo and the Ox Mountains (Fig. 1) did not, suggesting that Connemara was now the outboard edge of the Laurentian margin (Fig. 11). The possibility that Connemara always was the outer edge of the Laurentian margin with North Mayo behind seems unlikely because the South Mayo Trough could not have survived and continued to develop while being obducted over the Connemara Dalradian crust.

Early workers (Dewey 1971; Ryan and Archer 1977) suggested that the South Mayo Trough formed as a back-arc or extensional basin between Connemara and North Mayo Dalradian crust. This setting can be compared to the more recent interpretation of the Dashwoods block and related strata along the Humber margin of Newfoundland (Waldron and van Staal 2001), in which the Dashwoods block rifted off the Laurentian margin to form a small ocean basin between the two continental fragments. In such an analogy, Connemara would have formed a peri-Laurentian micro-continent, rifted off the Laurentian margin during opening of Iapetus, with the Lough Nafooey arc and South Mayo Trough in the intervening seaway. However, the coherence of Dalradian stratigraphy and early Grampian compressional deformation between North Mayo and Connemara are difficult to reconcile with generation of the South Mayo Trough in an extensional environment. We therefore propose that Connemara was translated from the Laurentian margin to a position south of the South Mayo Trough, but that this occurred before or during deposition of the base of the Mweelrea Formation at ca $464 \mathrm{Ma}$, earlier than previously considered. D3 sinistral fabrics in syntectonic intrusions in Connemara may record this emplacement. The Dalradian stratigraphy of Connemara is most like the north Mayo stratigraphy directly to the north (Long et al. 2006) and so the amount of strike-slip displacement appears to have been minor.

We propose the following basin model for the South Mayo Trough (Fig. 11). Prior to deposition of the Mweelrea Formation, oceanward-directed subduction led to obduction 
of the Lough Nafooey fore-arc over the Dalradian margin, causing the Grampian

461 (Taconic) orogeny (Ryan and Dewey 1991, van Staal et al. 1998). Obduction created the

462 Clew Bay ophiolite/accretionary complex, which provided a northerly supply of

463 ophiolitic sediment into South Mayo Trough basin (Wrafter and Graham 1989, Dewey

464 and Mange 1999). Our detrital zircon data show that the northerly ophiolite included

465 Cambro-Ordovician igneous rocks, and so is age-equivalent to the Baie Verte Oceanic

466 Tract of Newfoundland (van Staal et al. 1998). During the flip of subduction polarity

467 (Dewey 2005), lateral displacement of Connemara along the Laurentian margin

468 converted the South Mayo Trough to a strike-slip back-arc basin between two sectors of

469 the Laurentian margin. Connemara, to the south, became the locus of intrusion of the south-facing, Notre Dame magmatic arc (Fig. 11). The Mweelrea Formation continued to receive northerly derived sediment from the unroofed Dalradian metasedimentary rocks, and a new and coarse southerly supply of granitic and metamorphic sediment to the Bunnacunneen fan from Connemara, as detailed by our detrital zircon and clast petrology data. Basin-wide, ca 464 Ma ignimbrites in the Mweelrea Formation were probably erupted from the Connemara arc during Notre Dame magmatism. The ignimbrites have an evolved calc-alkaline composition suggesting derivation from a volcanic arc (Clift and Ryan 1994, Draut and Clift 2001). The Tourmakeady volcanic rocks, generally interpreted as the evolved, felsic phase of the Lough Nafooey arc, are unconformably overlain by South Mayo Trough sediments suggesting that the Lough Nafooey arc was inactive by this time.

Our basin model suggests that the Mweelrea Formation was deposited in an east-to-westflowing fluvial to deltaic system with the basin open to the west, consistent with the sedimentary evidence (Pudsey 1984a,b). The basin was closed to the east, so that along strike, farther east, the Notre Dame arc intruded the Laurentian margin proper, as is the case in Tyrone (north-central Ireland; Chew et al. 2008).

The direction of displacement of the Connemara block remains unresolved. Whilst the simplest solution to create the geometry depicted in Figure 11 is dextral movement, and whilst there is evidence of a dextral sense for the initial Grampian collision (van Staal et al. 1998) and later post-Silurian brittle fracturing (Power et al.2002), the main fabrics in the syn-tectonic Connemara arc intrusions and the D4 shear zones in Connemara are sinistral (Long et al. 2006). Our data do not constrain the sense of movement, but they do constrain its timing and the resultant basin configuration.

Clift et al. (in press) repeat the findings of Graham et al. (1991) and Clift et al. (2003), that Connemara was a southerly sediment source for the late Ordovician - Silurian Derryveeny conglomerate, but not for the Llanvirn Rosroe Formation, which underlies the Mweelrea Formation (Fig. 2). Previous interpretation of the Rosroe Formation as a southerly submarine fan (Archer 1977) has been disputed by more recent studies that indicate northerly palaeocurrents (Williams 2002, Clift et al. 2003). Clift et al. (in press) again infer that the Derryveeny conglomerate is the earliest evidence for Connemara to the south of the South Mayo Trough. That work, however, did not sample the Mweelrea Formation or its southerly derived Bunnacunneen conglomerate fan, which, in this paper, 
505 we clearly show to be a critical datum in understanding the emplacement history of the 506 Connemara block.

508 If the Connemara block was the southern source terrain for both the magmatic arc detritus

509 and juvenile volcanic input to the Mweelrea Formation (i.e. ignimbrites), then the internal 510 plutonic level of the arc was exposed while the arc was still volcanically active. This 511 interpretation is supported by the observation that the cooling history of the Connemara 512 metamorphic rocks (Elias et al. 1988, Friedrich et al.1999b) indicates rapid uplift during 513 D3 and D4 (ca 468-462 Ma), probably caused by intrusion of the large volume of 514 buoyant magma of the orthogneiss suite. D4 mylonitic shear fabrics in the most northern 515 exposed part of the Connemara block are sinistral obliquely down to the north. Uplift of 516 the currently exposed rocks presumably made higher, less-deformed levels available for 517 erosion. Magmatic arc activity continued until after D4, as seen in the undeformed ca 518462 Ma Oughterard Granite, so that it seems feasible that ignimbrites (ca $464 \mathrm{Ma}$ ) were 519 erupted while older plutonic rocks of the same arc were eroded.

521 We acknowledge the generous input of Barry Long to the development of these ideas and results.

522 We thank George Gerhels for assistance with zircon analysis, and Clive Murray, Chris

523 McDonnell, and Rebecca Gould for sample preparation. At NIGL, Adrian Wood performed

524 mineral separation, Aaran Sumner and Neil Boulton provided technical assistance with TIMS

525 work and Matt Horstwood and Vanessa Pashley assisted with laser ablation MC-ICPMS analysis. 526 BMcC publishes with permission of the Director of GSI. Comments by Peter Cawood, Ian

527 Millar, two anonymous reviewers and Subject Editor Sarah Sherlock improved previous versions 528 of this manuscript. 
Archer, J.B. 1977. Llanvirn stratigraphy of the Galway-Mayo border area, western Ireland. Geological Journal, 12, 77-98.

Bradshaw, R.V., Plant, A.G., Burke, K.C. \& Leake, B.E. 1969. The Oughterard granite, Connemara, Co. Galway. Proceedings of the Royal Irish Academy, 68B, 39-65.

Cawood, P.A. \& van Gool, J.A.M. 1998. Geology of the Corner Brook - Glover Island Region. Geological Survey of Canada, Bulletin 427, Ottawa, 96pp.

Cawood, P.A., Nemchin, A.A., Smith, M. \& Loewy, S. 2003. Source of the Dalradian Supergroup constrained by U-Pb dating of detrital zircon and implications for the East Laurentian margin. Journal of the Geological Society, London, 160, 231-246.

Cawood, P.A., Nemchin, A.A., Strachan, R.A., Prave, A.R. \& Krabbendam, M. 2007. Sedimentary basin and detrital zircon record along East Laurentia and Baltica during assembly and breakup of Rodinia. Journal of the Geological Society, London, 164, 257275.

Chew, D.M., Flowerdew, M.J., Page, L.M., Crowley, Q.G., Daly, J.S., Cooper, M. \& Whitehouse, M.J. 2008. The tectonothermal evolution and provenance of the Tyrone Central Inlier, Ireland: Grampian imbrication of an outboard Laurentian microcontinent? Journal of the Geological Society, London, 165, 675-685.

Chew, D.M., Graham, J.R. \& Whitehouse, M.J. 2007. U-Pb zircon geochronology of plagiogranites from the Lough Nafooey (=Midland Valley) arc in western Ireland: constraints on the onset of the Grampian orogeny. Journal of the Geological Society, London, 164, 747-750.

Clift, P.D., Carter, A., Draut, A.E., van Long, H., Chew, D.M. and Schouten, H.A. (in press). Detrital U-Pb zircon dating of lower ordovician syn-arc-continent collision conglomerates in the Irish Caledonides. Tectonophysics. doi:10.1016/j.tecto.2008.07.018

Clift, P.D., Draut, A.E., Hannigan, R., Layne, G. \& Blusztajn, J. 2003. Trace element and $\mathrm{Pb}$ isotopic constraints on the provenance of the Rosroe and Derryveeny formations, South Mayo, Ireland. Transactions of the Royal Society of Edinburgh: Earth Sciences, 93, 101-110.

Clift, P.D. \& Ryan, P.D. 1994. Geochemical evolution of an Ordovician island arc. Journal of the Geological Society, London, 151, 329-342.

Dewey, J.F. 1963. The Lower Palaeozoic stratigraphy of Central Murrisk, Co. Mayo, Ireland and the evolution of the South Mayo Trough. Journal of the Geological Society, London, 119, 313-344. 
576
Dewey, J.F. 1971. A model for the Lower Palaeozoic evolution of the southern margin of the early Caledonides of Scotland and Ireland. Scottish Journal of Geology, 7, 219-240.

Dewey, J.F. 2005. Orogeny can be very short. Proceedings of the National Academy of Sciences, 102, 15286-15293.

Dewey, J. \& Mange, M. 1999. Petrography of Ordovician and Silurian sediments in the western Irish Caledonides: tracers of a short-lived Ordovician continent-arc collision orogeny and the evolution of the Laurentian Appalachian-Caledonian margin. In: MacNiocaill, C. and Ryan, P.D. (eds) Continental Tectonics. Geological Society, London, Special Publications, 164, 55-107.

Draut, A.E. \& Clift, P.D. 2002. Geochemical evolution of arc magmatism during arccontinent collision, South Mayo, Ireland. Geology, 29, 543-546.

Dunning, G.R. \& Krogh, T.E. 1985. Geochronlogy of ophiolites of the Newfoundland Appalachians. Canadian Journal of Earth Sciences, 22, 1659-1670.

Elias, E.M., MacIntyre, R.M. \& Leake, B.E. 1988. The cooling history of Connemara, western Ireland, from K-Ar and Rb-Sr age studies. Journal of the Geological Society, London, 145, 649-660.

Elliott, C.G., Dunning, G.R. \& Williams, P.F. 1991. New constraints on the timing of deformation in eastern Notre Dame Bay, Newfoundland, from U/Pb zircon ages of felsic intrusions. Geological Society of America Bulletin, 103, 125-135.

Flowerdew, M.J., Daly, J.S. \& Whitehouse, M.J. 2005. 470Ma granitoid magmatism associated with the Grampian Orogeny in the Slishwood Division, NW Ireland. Journal of the Geological Society, London, 162, 563-575.

Fortey, R.A., Harper, D.A.T., Ingham, J.K., Owen, A.W. \& Rushton, A.W.A. 1995. A revision of Ordovician series and stages from the historical type area. Geological Magazine, 132, 15-30.

Friedrich, A.M., Bowring, S.A., Martin, M.W. \& Hodges, K.V. 1999a. Short-lived continental magmatic arc at Connemara, western Irish Caledonides: Implications for the age of the Grampian orogeny. Geology, 27, 27-30.

Friedrich, A.M., Hodges, K.V., Bowring, S.A. \& Martin, M.W. 1999b. Geochronological constraints on the magmatic, metamorphic and thermal evolution of the Connemara Caledonides, western Ireland. Journal of the Geological Society, London, 156, 1217-1230.

Gradstein, F.M., Ogg, J.G., Smith, A.G. et al. 2004. A Geologic Time Scale 2004. Cambridge University Press.

Graham, J.R., Wrafter, J.P., Daly, J.S. \& Menuge, J.F. 1991. A local source for the 
622 Ordovician Derryveeny Formation, western Ireland: implications for the Connemara

623 Dalradian. In: Morton, A.C., Todd, S.P. and Haughton, P.D.W. (eds) Developments in

624 Sedimentary Provenance Studies. Geological Society, London, Special Publications, 57,

625 199-213.

626

Harper, D.A.T. \& Parkes, M.A. 2000. Ireland. In: Fortey, R.A. et al (eds) A Revised

628 Correlation of the Ordovician rocks in the British Isles. The Geological Society, Special

Hutton, D.H.W. 1987. Strike slip terranes and a model for the evolution of the British and Irish Caledonides. Geological Magazine, 124, 405-425.

Jenner, G.A., Dunning, G.R., Malpas, J., Brown, M. \& Brace, T. 1991. Bay of Islands and Littleport complexes, revisited: age, geochemical and isotopic evidence confirm suprasubduction-zone origin. Canadian Journal of Earth Sciences, 28, 1635-1652.

Leake, B.E. 1989. The metagabbros, orthogneisses and paragneisses of the Connemara complex, western Ireland. Journal of the Geological Society, London, 146, 575-596.

Long, C.B., McConnell B.J. \&. Philcox M.E. 2006. Geology Of South Mayo: A geological description to accompany the Bedrock Geology 1:100,000 scale Map Series, Sheet 11, South Mayo. Geological Survey of Ireland.

Pearce, J.A., Harris, N.B.W. \& Tindle, A.G. 1984 Trace element discrimination diagrams for the tectonic interpretation of granitic rocks. Journal of Petrology, 25, 956-983.

Peccerillo, A. \& Taylor, S.R. 1976. Geochemistry of Eocene calc-alkaline volcanic rocks from the Kastamonu area, northern Turkey. Contributions to Mineralogy and Petrology, 58, 63-81.

Power, S.E., Ryan, P.D. \& Feely, M. 2002. Structural and fluid-inclusion studies of north-west Connemara, west of Ireland (abstract). Irish Journal of Earth Sciences, 20, 98.

Pudsey, C.J. 1984a. Ordovician stratigraphy and sedimentology of the South Mayo inlier. Irish Journal of Earth Sciences, 6, 15-45.

Pudsey, C.J. 1984b. Fluvial to marine transition in the Ordovician of Ireland - a humid region fan delta? Geological Journal, 19, 143-172.

Ryan, P.D. \& Archer, J.B. 1977. The South Mayo Trough: a possible Ordovician Gulf of California-type marginal basin in W. Ireland. Canadian Journal of Earth Sciences, 14, 2453-2461.

Ryan, P.D. \& Dewey, J.F. 1991. A geological and tectonic cross-section of the Caledonides of western Ireland. Journal of the Geological Society, London, 148, 173- 
180.

Soper, N.J., Ryan, P.D. \& Dewey, J.F. 1999. Age of the Grampian orogeny in Scotland and Ireland. Journal of the Geological Society, London, 156, 1231-1236.

Stanton, W.I. 1960. The Lower Palaeozoic rocks of south-west Murrisk, Ireland. Quarterly Journal of the Geological Society, London, 116, 269-296.

Ufnar, D.F., Smith, D.P. \& White, J.D.L. 1995. Preservation potential of ultrabasic volcanic sand in an arid introcontinental setting: will the Hopi Buttes maar-diatreme field be preserved in the rock record? Journal of Sedimentary Research, A65, 99-104.

Van Staal, C.R., Dewey, J.F., MacNiocaill, C. \& McKerrow, W.S. 1998. The CambrianSilurian tectonic evolution of the northern Appalachians and British Caledonides: history of a complex, west and southwest Pacific-type segment of Iapetus. In: Blundell, D.J. and Scott, A.C. (eds) Lyell: the Past is the Key to the Present. Geological Society, London, Special Publications, 143, 199-242.

Waldron, J.W.F. \& van Staal, C.R. 2001. Taconian orogeny and the accretion of the Dashwoods block: A peri-Laurentian microcontinent in the Iapetus Ocean. Geology, 29, 811-814.

Williams, A. 1972. An Ordovician Whiterock fauna in western Ireland. Proceedings of the Royal Irish Academy, B72, 209-219.

Williams, D.M. 1984. The stratigraphy and sedimentology of the Ordovician Partry Group, southeastern Murrisk, Ireland. Geological Journal, 19, 173-186.

Williams, D.M. 2002. Buried oblique-slip faults in the Irish Caledonides. Geological Journal 37, 135-142.

701

Wrafter, J.P. \& Graham, J.R. 1989. Ophiolitic detritus in the Ordovician sediments of South Mayo, Ireland. Journal of the Geological Society, London, 146, 213-215. 


\section{Tables}

703 Table 1. U-Pb ID-TIMS zircon data from a Bunnacunneen conglomerate granite cobble

704 (sample 03/04b).

705

706

707

708

709

710

711

712

713

714

715

716

717

718

719

720
Table 2. Major (wt \%) and trace (ppm) element data for granitoid clasts from the Bunnacunneen conglomerate

\section{Figures}

Fig. 1. Regional geological map of Mayo and Connemara. Grid is Irish National Grid. FHCBL = Fair Head - Clew Bay lineament. Inset shows positions of Ireland and Newfoundland in the Appalachian-Caledonian orogen (ca 400Ma).

Fig. 2. Stratigraphy of the South Mayo Trough. In this paper, we use the classical Series subdivisions of the Ordovician Period (as modified by Fortey et al. 1995), because the ages of rocks in the South Mayo Trough have been assigned using this scheme over a long history of geological research. The table shows correlation of the British Series and graptolite Biozones to the Global Stages and numerical time scale of Gradstein et al. (2004). Asterisks show fossil age control; ig1-4 are ignimbrites 1 to 4 (approximate stratigraphical level, but note, ignimbrites are separated by sandstone), ig5 is ignimbrite 5; IB1 is U-Pb zircon date of ignimbrite 1 from Dewey and Mange (1999); age range of Connemara magmatic arc from Friedrich et al. (1999a)

Fig. 3. Simplified map of the Mweelrea Formation and surrounding rocks showing sample localities. Grid is Irish National Grid

Fig. 4. Conglomerate of the Bunnacunneen member, Mweelrea Formation, at Lough Nafooey. Clasts, up to $90 \mathrm{~cm}$ across, include granite, quartz-porphyry, psammite and vein quartz

Fig. 5. A. Age-probability plot of detrital zircons from Bundorragha sandstone (samples 03/230 and 07/102; for location see Fig. 3). B. Age-probability and TuffZirc (insert) plots concentrating on Cambrian and Ordovician grains. Lighter shade indicates analysis not included for median TuffZirc age calculation.

Fig. 6. Age-probability plot of detrital zircons from Derrintin sandstone (sample 07/101; for location see Fig. 3). B. Age-probability and TuffZirc (insert) plots concentrating on Cambrian and Ordovician grains. Lighter shade indicates analysis not included for median TuffZirc age calculation.

Fig. 7. A. Age-probability plot of detrital zircons from lower Bunnacunneen sandstone. (samples 03/227 and 07/104; for location see Fig. 3). B. Age-probability and TuffZirc (insert) plots concentrating on Cambrian and Ordovician grains. Lighter shade indicates analysis not included for median TuffZirc age calculation.

Fig. 8. A. Age-probability plot of detrital zircons from upper Bunnacunneen sandstone. (samples 03/228 and 07/103; for location see Fig. 3). B. Age-probability and TuffZirc 
748 (insert) plots concentrating on Cambrian and Ordovician grains. Lighter shade indicates 749 analysis not included for median TuffZirc age calculation.

751 Fig. 9. U-Pb Concordia diagram of ID-TIMS data for sample 03/04b. A. All analysed

752 fractions. B. Concordant fractions at ca $471 \mathrm{Ma}$.

754 Fig. 10. Geochemical plots for Bunnacunneen granite clasts: (a) $\mathrm{K}_{2} \mathrm{O}$ v. $\mathrm{SiO}_{2}$ plot, fields 755 from Peccerillo and Taylor (1976); (b) trace element profiles normalized to Ocean Ridge 756 Granite, garnetiferous samples open dots, shaded area is field of Connemara granitic 757 orthogneiss suite (Leake 1989), normalizing values from Pearce et al. (1984); (c) tectonic 758 setting discriminant diagram (Pearce et al. 1984), VAG= volcanic arc granite, $\mathrm{ORG}=$ 759 ocean ridge granite, WPG= within plate granite, syn-COLG=syn-collisional granite; (d) 760 Rare Earth Elements normalized to Chondrite, garnetiferous samples open dots.

761

762 Fig. 11. Schematic diagram showing the South Mayo Trough in Llanvirn times (ca 464 $763 \mathrm{Ma})$; see text for explanation. 


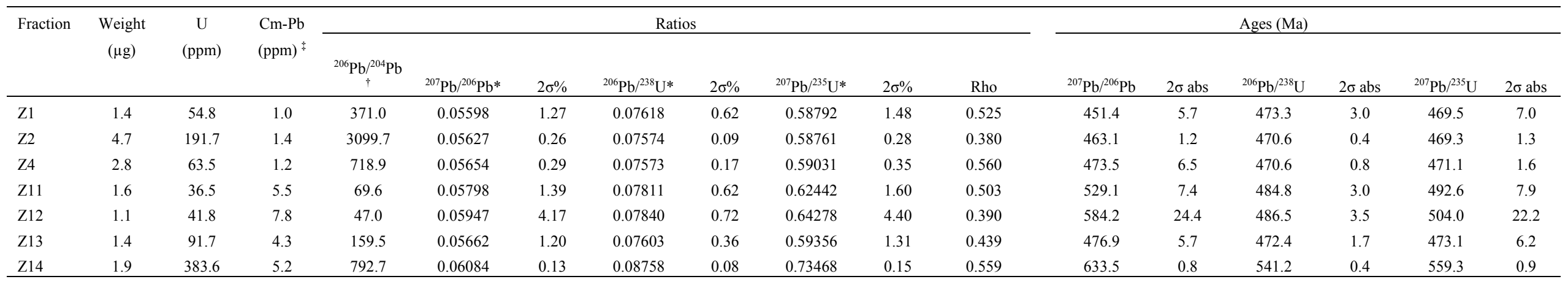

All errors are $2 \sigma$ (per cent for ratios, absolute for ages)

$\ddagger$ Total common $\mathrm{Pb}$ in analysis, corrected for spike and fractionation

$\dagger$ Measured ratio, corrected for spike and $\mathrm{Pb}$ fractionation

* Corrected for blank Pb, U and common Pb (Stacey and Kramers 1975) 
Table 2. Major (wt \%) and trace (ppm) element data for granitoid clasts from the Bunnacunneen conglomerate.

\begin{tabular}{lrrrrrrrr}
$\mathrm{Sample}$ & $\mathbf{0 3 / 0 1}$ & $\mathbf{0 3 / 0 2}$ & $\mathbf{0 3 / 0 3}$ & $\mathbf{0 3 / 0 4}$ & $\mathbf{0 3 / 0 5}$ & $\mathbf{0 3 / 0 6}$ & $\mathbf{0 3 / 0 7}$ & $\mathbf{0 3 / 0 8}$ \\
\cline { 2 - 4 } $\mathrm{SiO}_{2}$ & 73.0 & 73.2 & 72.6 & 78.0 & 75.0 & 77.5 & 73.7 & 82.7 \\
$\mathrm{TiO}_{2}$ & 0.25 & 0.30 & 0.34 & 0.07 & 0.19 & 0.07 & 0.31 & 0.10 \\
$\mathrm{Al}_{2} \mathrm{O}_{3}$ & 13.0 & 13.4 & 13.5 & 12.3 & 13.3 & 12.2 & 13.7 & 9.4 \\
$\mathrm{Fe}_{2} \mathrm{O}_{3}{ }^{\mathrm{t}}$ & 2.45 & 2.42 & 2.82 & 0.70 & 1.42 & 1.08 & 2.69 & 0.96 \\
$\mathrm{MnO}$ & 0.06 & 0.07 & 0.09 & 0.08 & 0.03 & 0.02 & 0.05 & 0.02 \\
$\mathrm{MgO}$ & 0.86 & 0.94 & 1.08 & 0.06 & 0.41 & 0.19 & 0.77 & 0.21 \\
$\mathrm{CaO}$ & 1.77 & 1.21 & 1.62 & 0.51 & 2.06 & 0.61 & 1.45 & 0.47 \\
$\mathrm{Na}_{2} \mathrm{O}$ & 4.81 & 5.94 & 5.45 & 5.23 & 4.00 & 6.29 & 4.78 & 4.98 \\
$\mathrm{~K}_{2} \mathrm{O}$ & 1.30 & 1.26 & 1.05 & 2.90 & 2.37 & 1.15 & 1.41 & 0.70 \\
$\mathrm{P}_{2} \mathrm{O}_{5}$ & 0.04 & 0.17 & 0.15 & 0.01 & 0.03 & 0.01 & 0.06 & 0.01 \\
$\mathrm{LOI}$ & 2.00 & 1.31 & 1.11 & 0.46 & 0.82 & 0.99 & 1.27 & 0.59 \\
$\mathrm{Total}$ & 99.6 & 100.2 & 99.7 & 100.3 & 99.7 & 100.2 & 100.1 & 100.1 \\
& & & & & & & & \\
$\mathrm{Ba}$ & 496 & 403 & 344 & 446 & 1510 & 264 & 519 & 225 \\
$\mathrm{Rb}$ & 30 & 50 & 35 & 85 & 58 & 31 & 56 & 18 \\
$\mathrm{Sr}$ & 150 & 174 & 159 & 84 & 225 & 72 & 188 & 129 \\
$\mathrm{Y}$ & 21 & 20 & 19 & 38 & 19 & 23 & 14 & 10 \\
$\mathrm{Zr}$ & 88 & 110 & 119 & 60 & 134 & 41 & 126 & 54 \\
$\mathrm{Nb}$ & 12 & 13 & 14 & 17 & 13 & 15 & 10 & 5.5 \\
$\mathrm{Th}$ & 8.2 & 11.4 & 11.8 & 16.5 & 8.9 & 13.1 & 5.5 & 8.6 \\
$\mathrm{~Pb}$ & 5.1 & 3.9 & 6.6 & 10.8 & 5.7 & 2.6 & 2.6 & 2.8 \\
$\mathrm{Hf}$ & 3.4 & 2.6 & 3.2 & 1.2 & 3.1 & 1.2 & 3.6 & 1.8 \\
$\mathrm{Ta}$ & 3.8 & 2.4 & 4.1 & 4.3 & 3.6 & 5.8 & 3.3 & 4.9 \\
$\mathrm{U}$ & 2.4 & 2.5 & 2.5 & 2.8 & 2.6 & 2.7 & 1.5 & 3.3 \\
$\mathrm{Mo}$ & 1.3 & 1.5 & 3.1 & 1.7 & 0.5 & 0.9 & 0.5 & 1.9 \\
$\mathrm{La}$ & 31 & 22 & 33 & 23 & 45 & 14 & 23 & 11 \\
$\mathrm{Ce}$ & 57 & 44 & 59 & 49 & 77 & 28 & 42 & 22 \\
$\mathrm{Pr}$ & 6.3 & 4.9 & 6.9 & 6.1 & 8.7 & 3.4 & 4.5 & 2.6 \\
$\mathrm{Nd}$ & 25 & 19 & 29 & 28 & 34 & 15 & 18 & 11 \\
$\mathrm{Sm}$ & 5.4 & 4.0 & 6.2 & 7.7 & 6.1 & 4.2 & 3.7 & 2.6 \\
$\mathrm{Eu}$ & 0.92 & 0.70 & 0.96 & 0.48 & 1.28 & 0.55 & 0.80 & 0.52 \\
$\mathrm{Gd}$ & 4.3 & 3.2 & 4.4 & 7.7 & 4.0 & 4.7 & 2.9 & 1.9 \\
$\mathrm{Dy}$ & 4.4 & 3.5 & 4.7 & 8.0 & 3.6 & 6.0 & 3.0 & 2.0 \\
$\mathrm{Er}$ & 2.8 & 2.1 & 2.7 & 4.6 & 2.1 & 3.7 & 1.8 & 1.3 \\
$\mathrm{Yb}$ & 2.7 & 2.0 & 2.7 & 4.4 & 2.3 & 3.7 & 1.8 & 1.3 \\
$\mathrm{Lu}$ & & 0.31 & 0.4 & 0.65 & 0.55 & 0.55 & 0.27 & 0.19
\end{tabular}




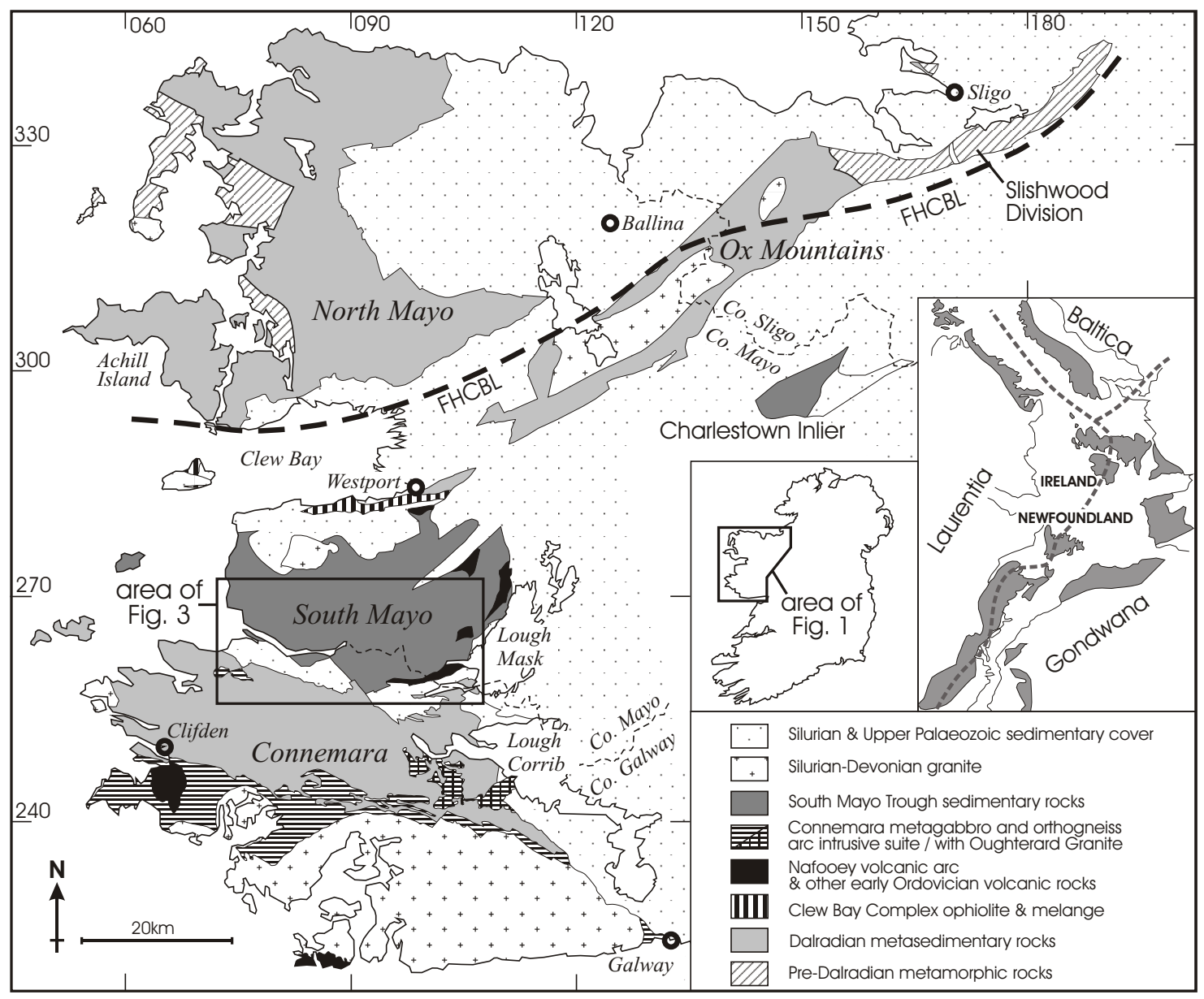




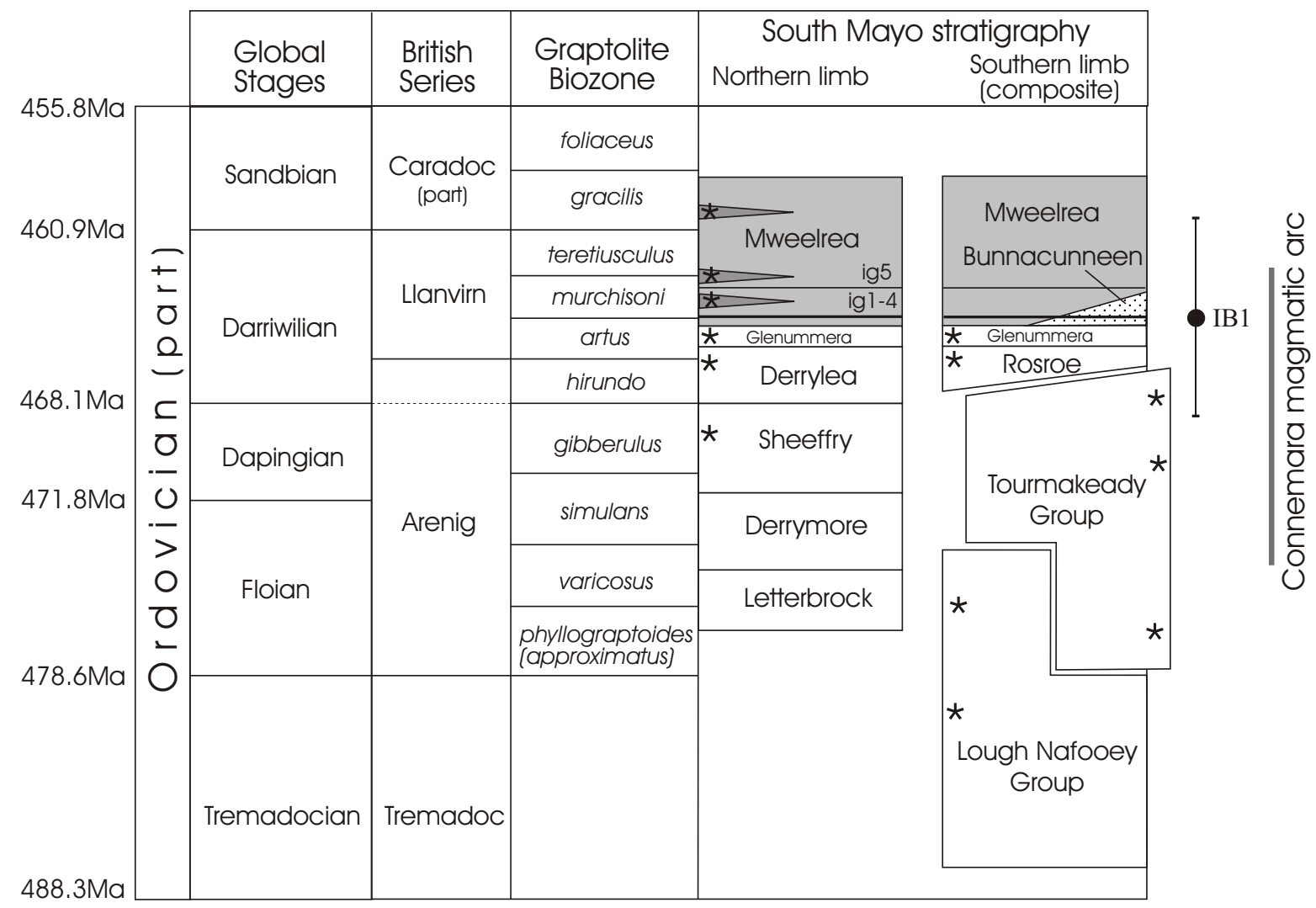




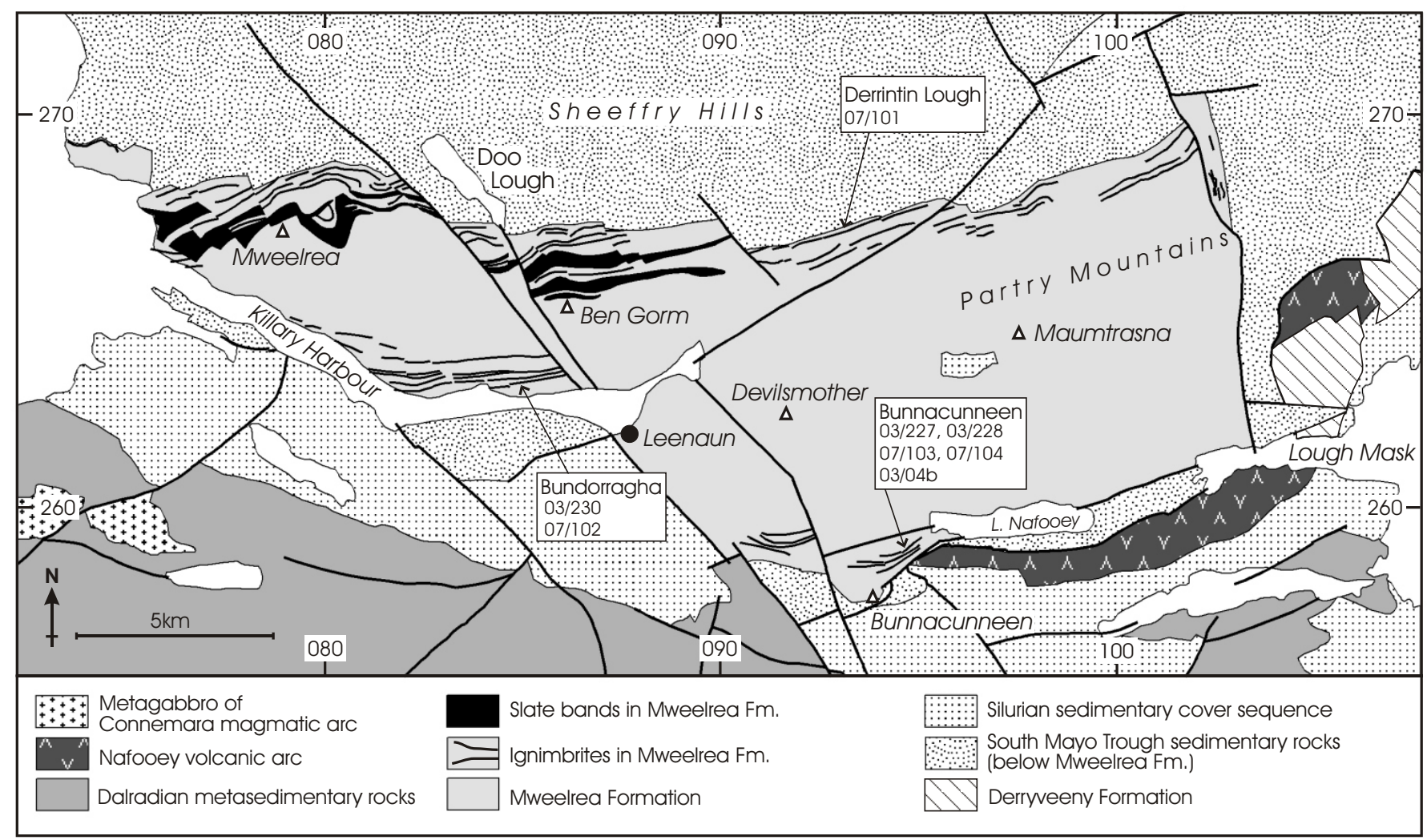




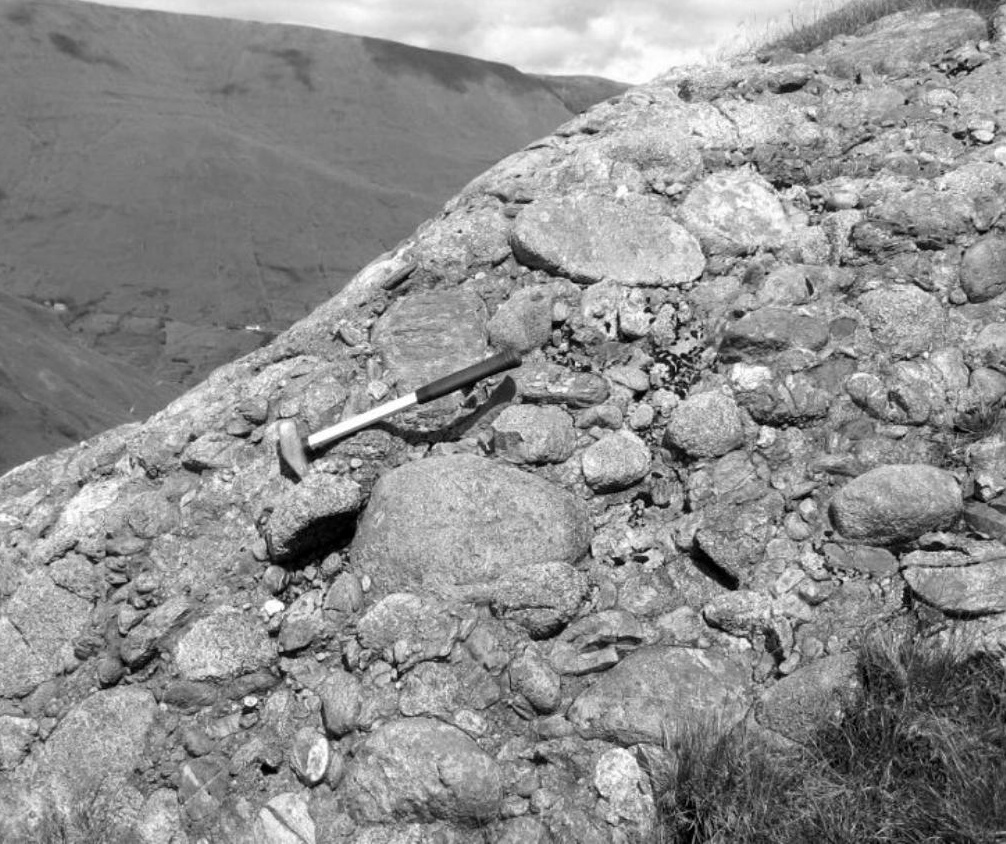




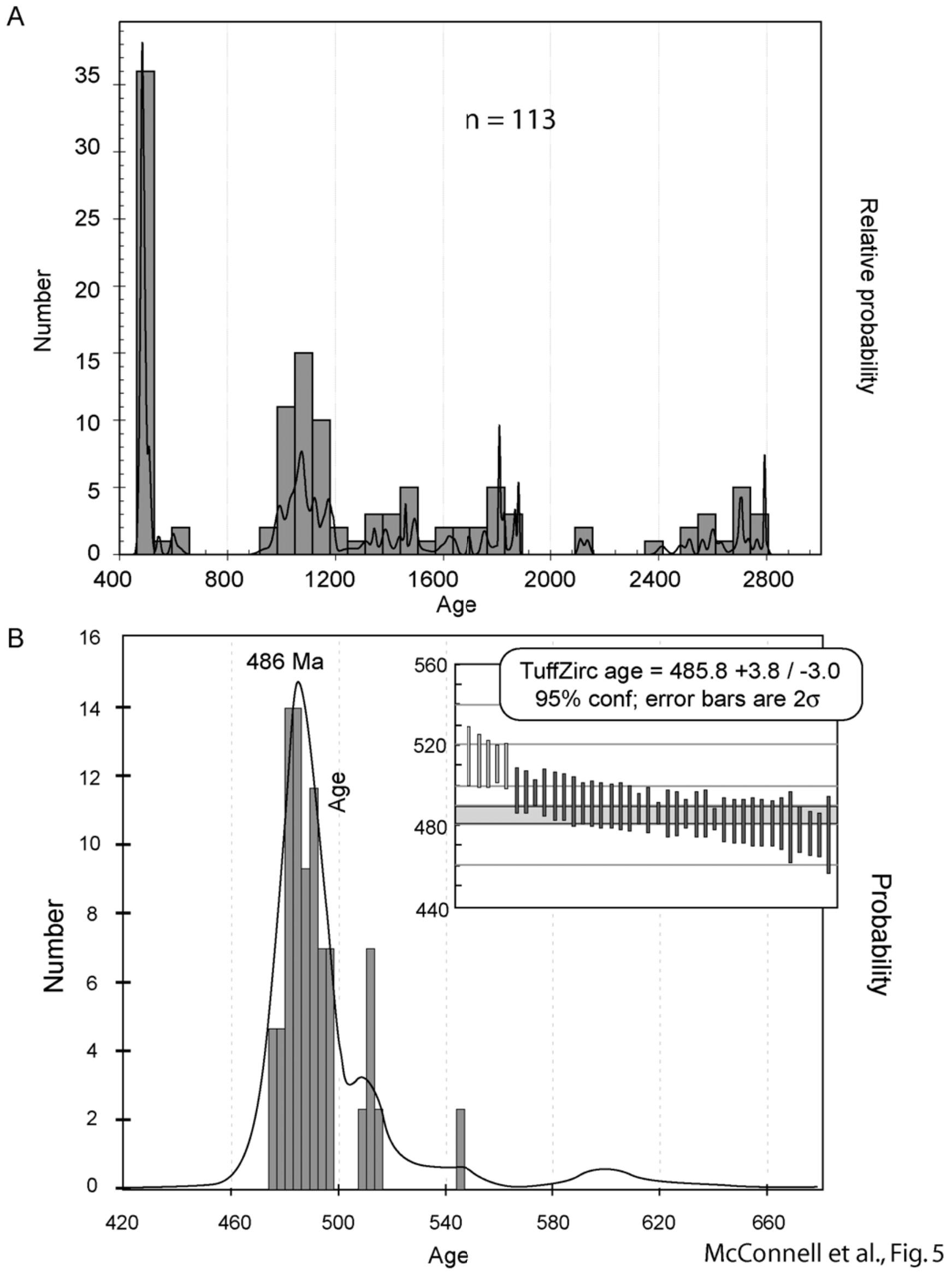



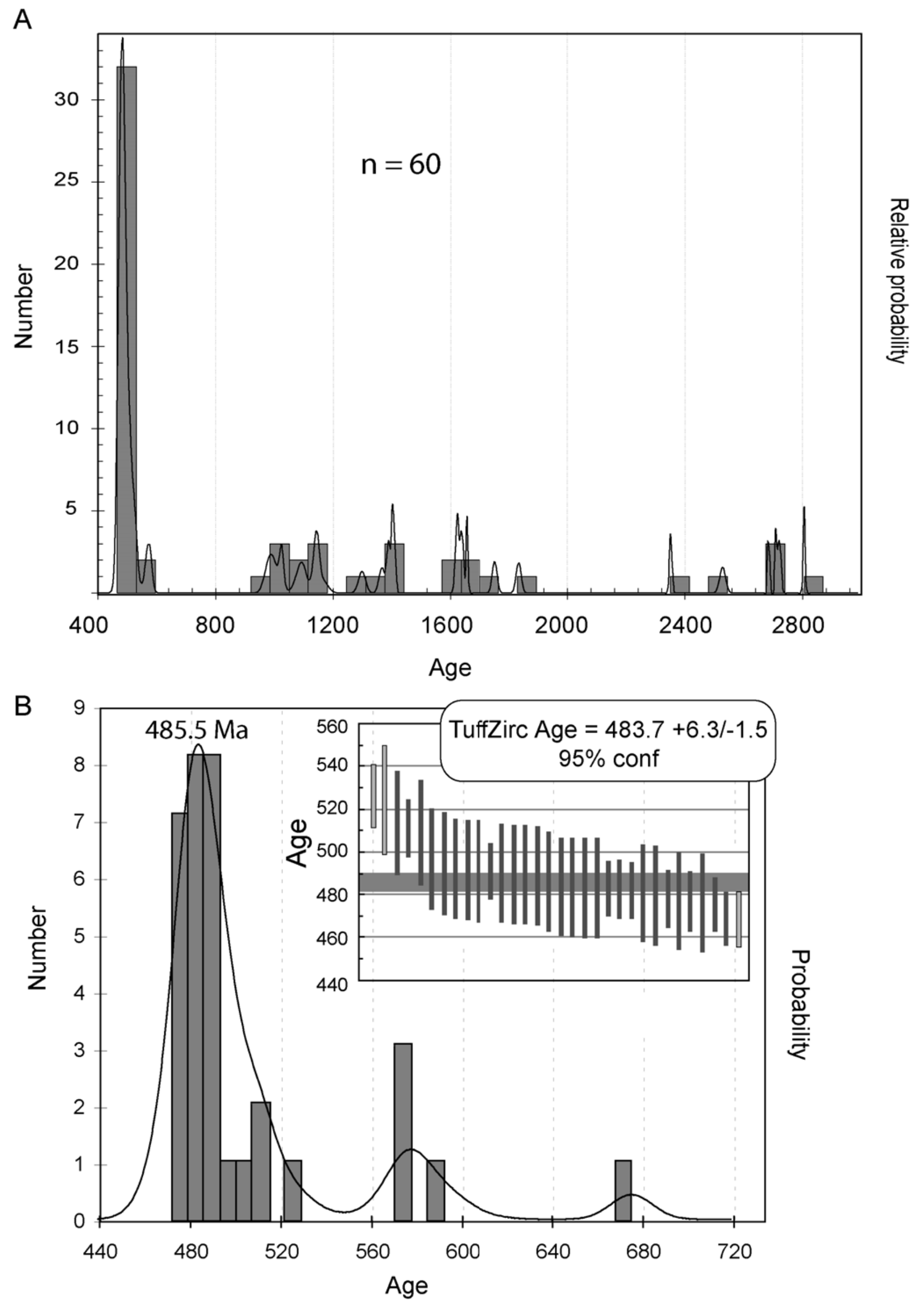
A

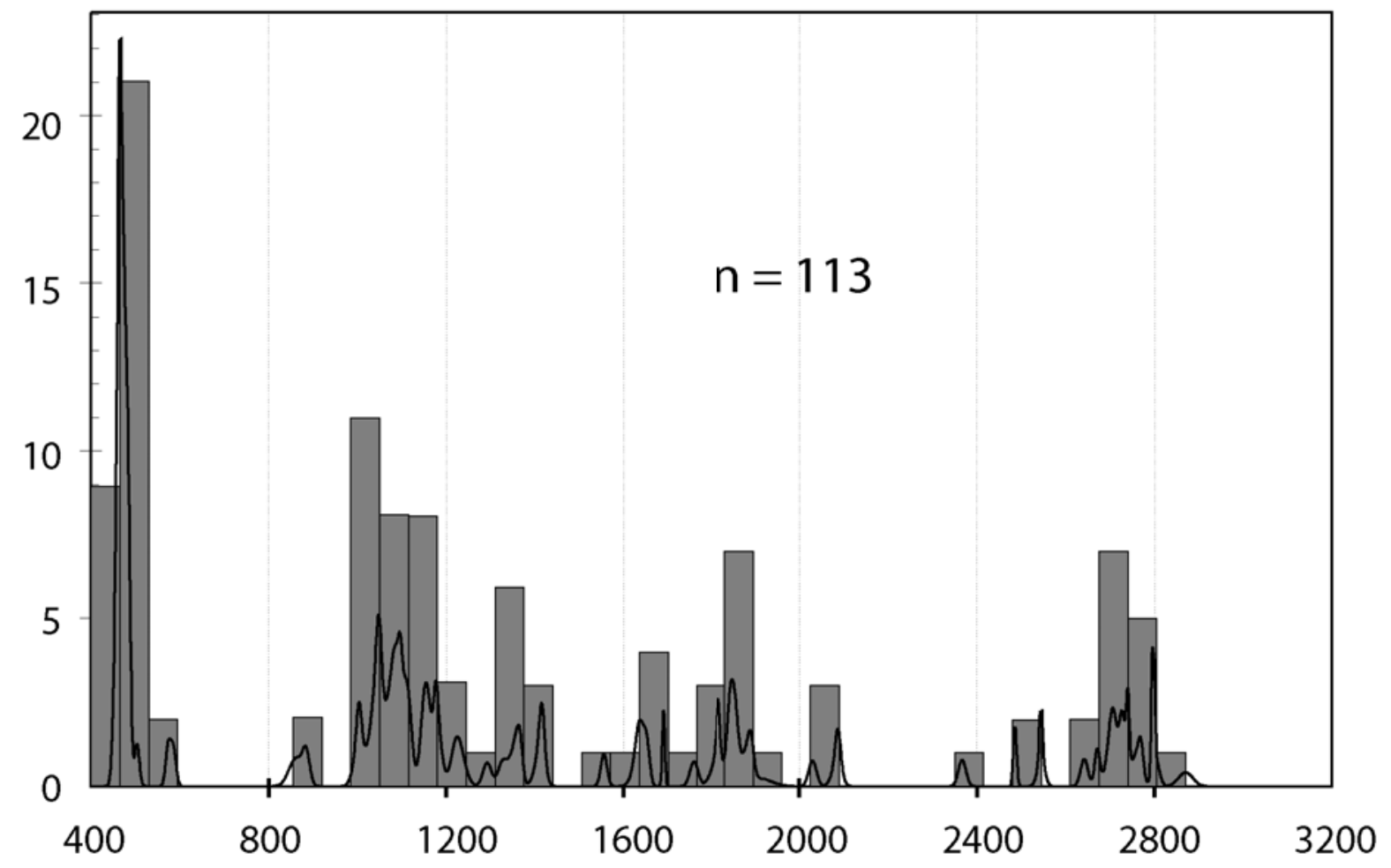

B

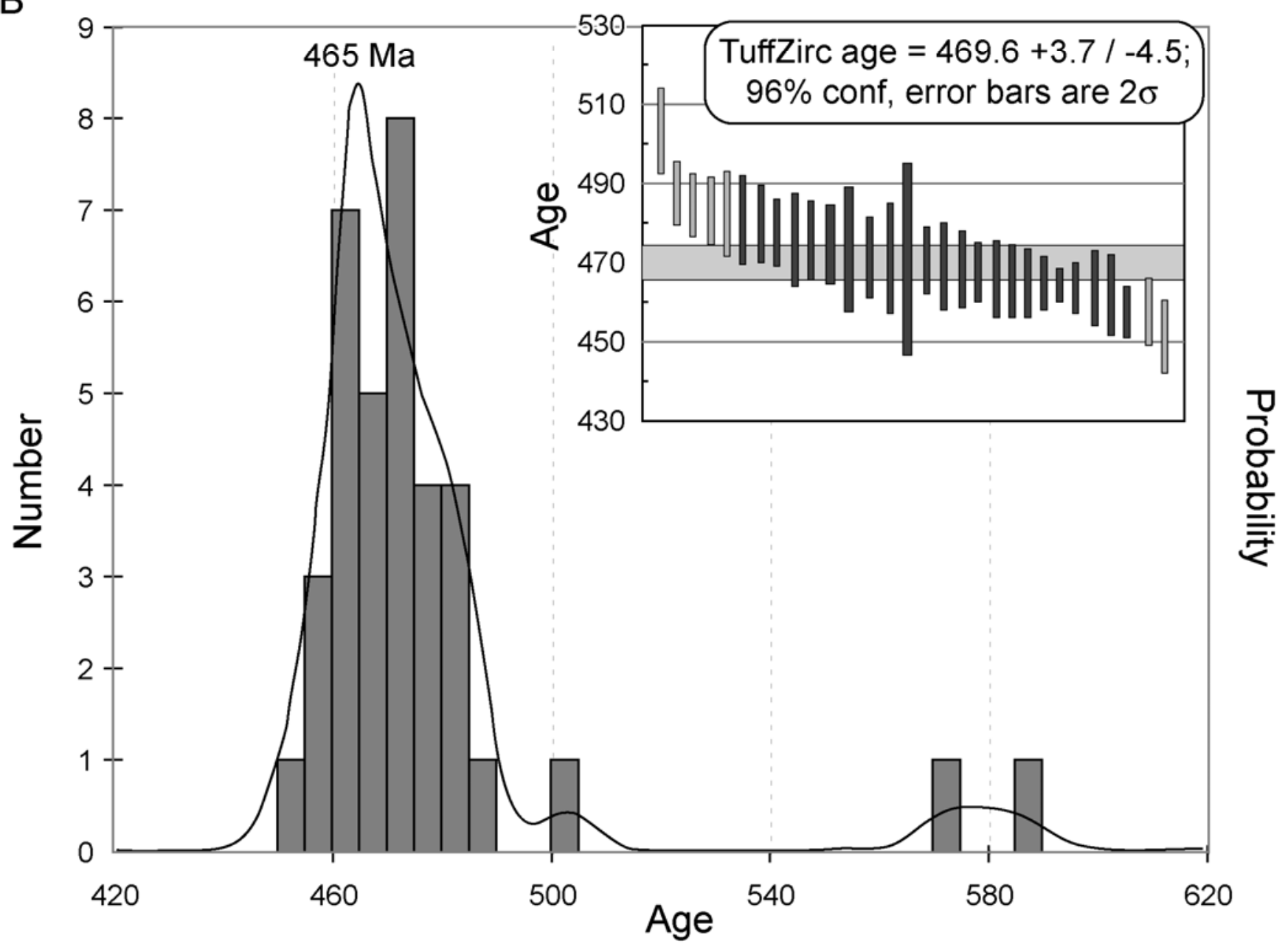

McConnell et al., Fig. 7 


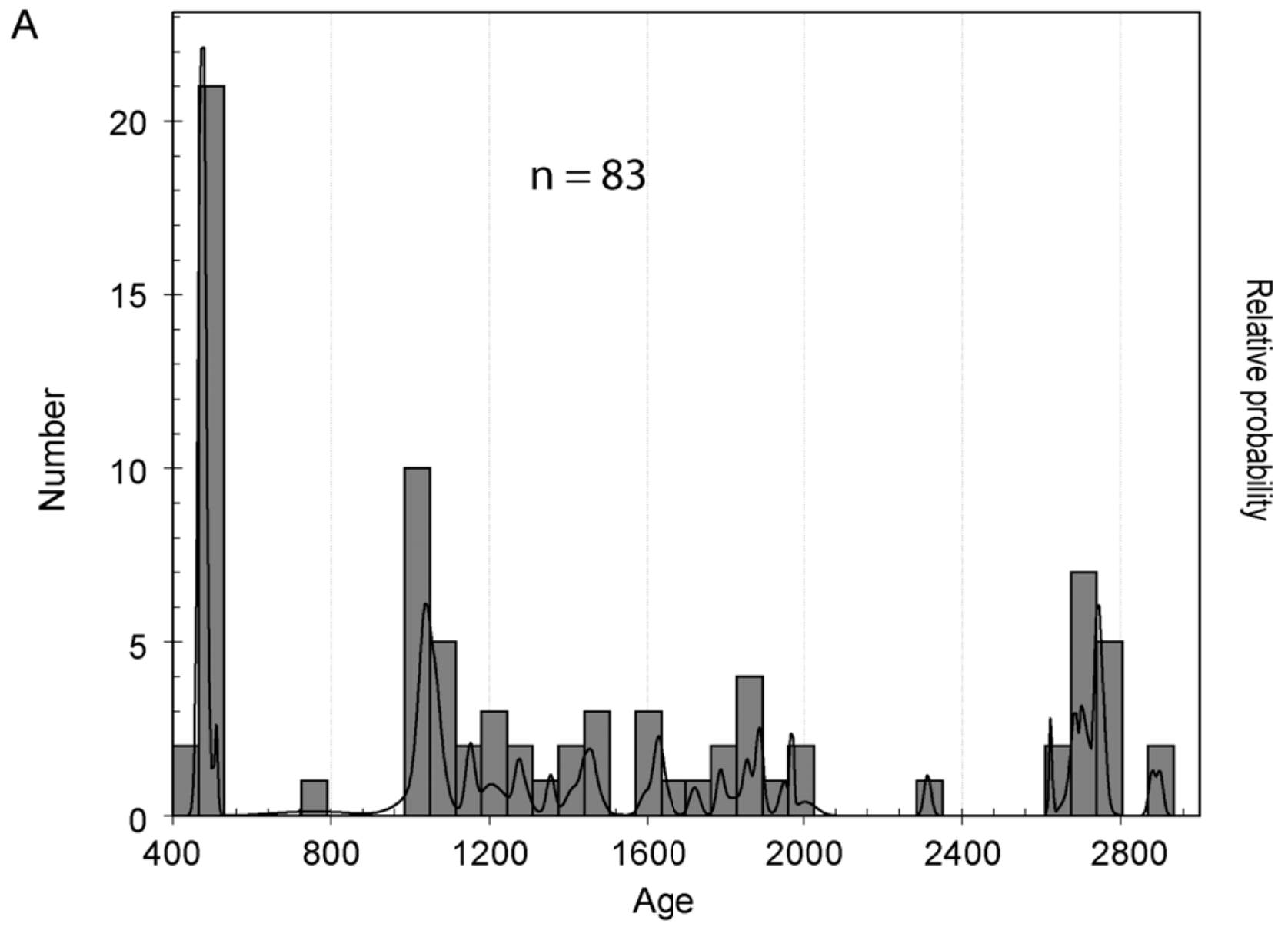

B

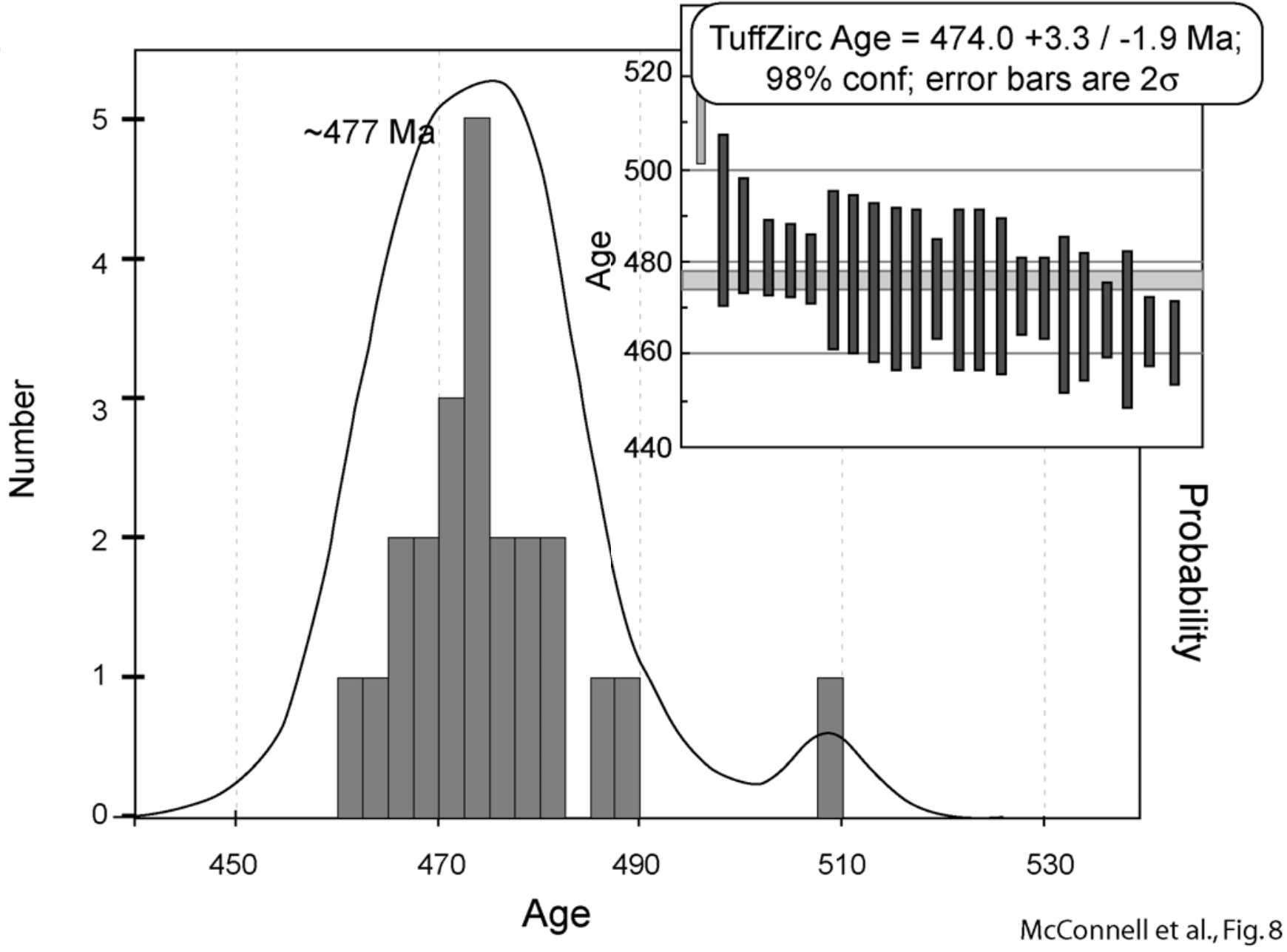



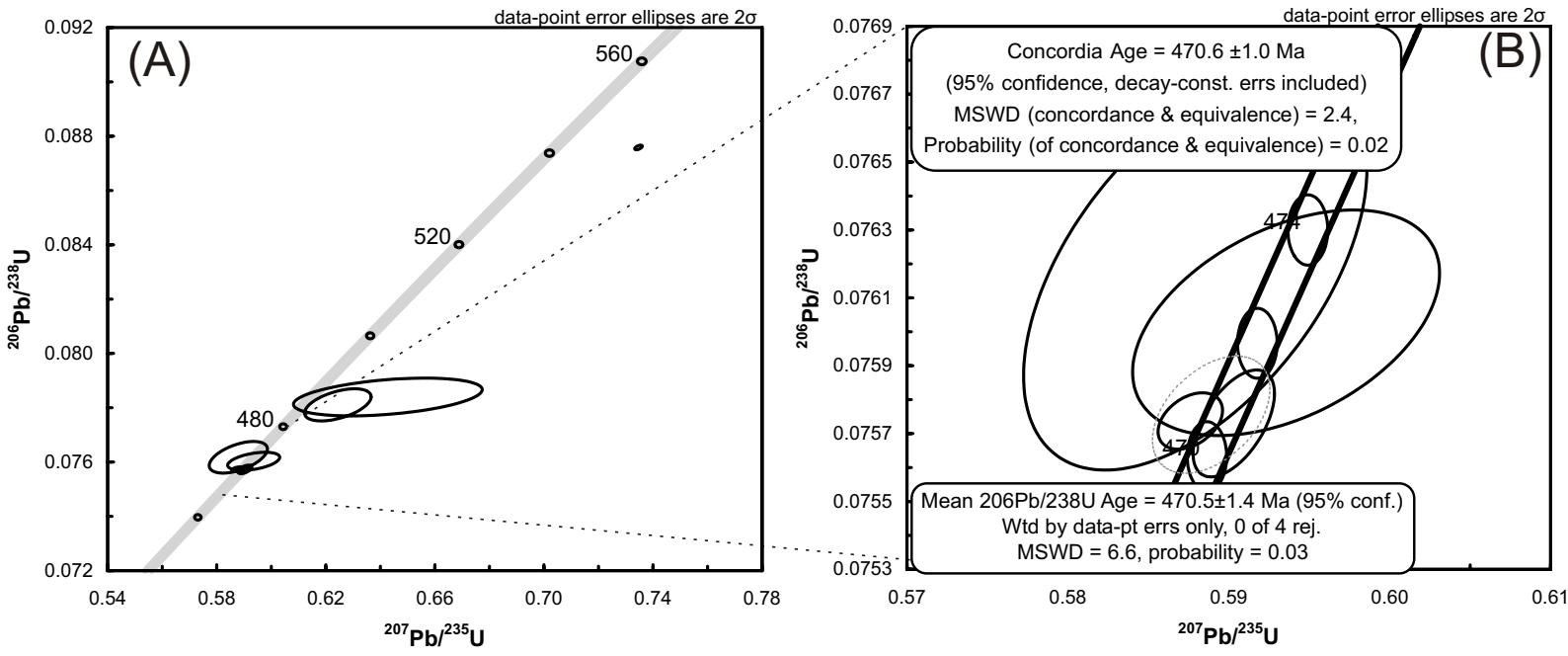

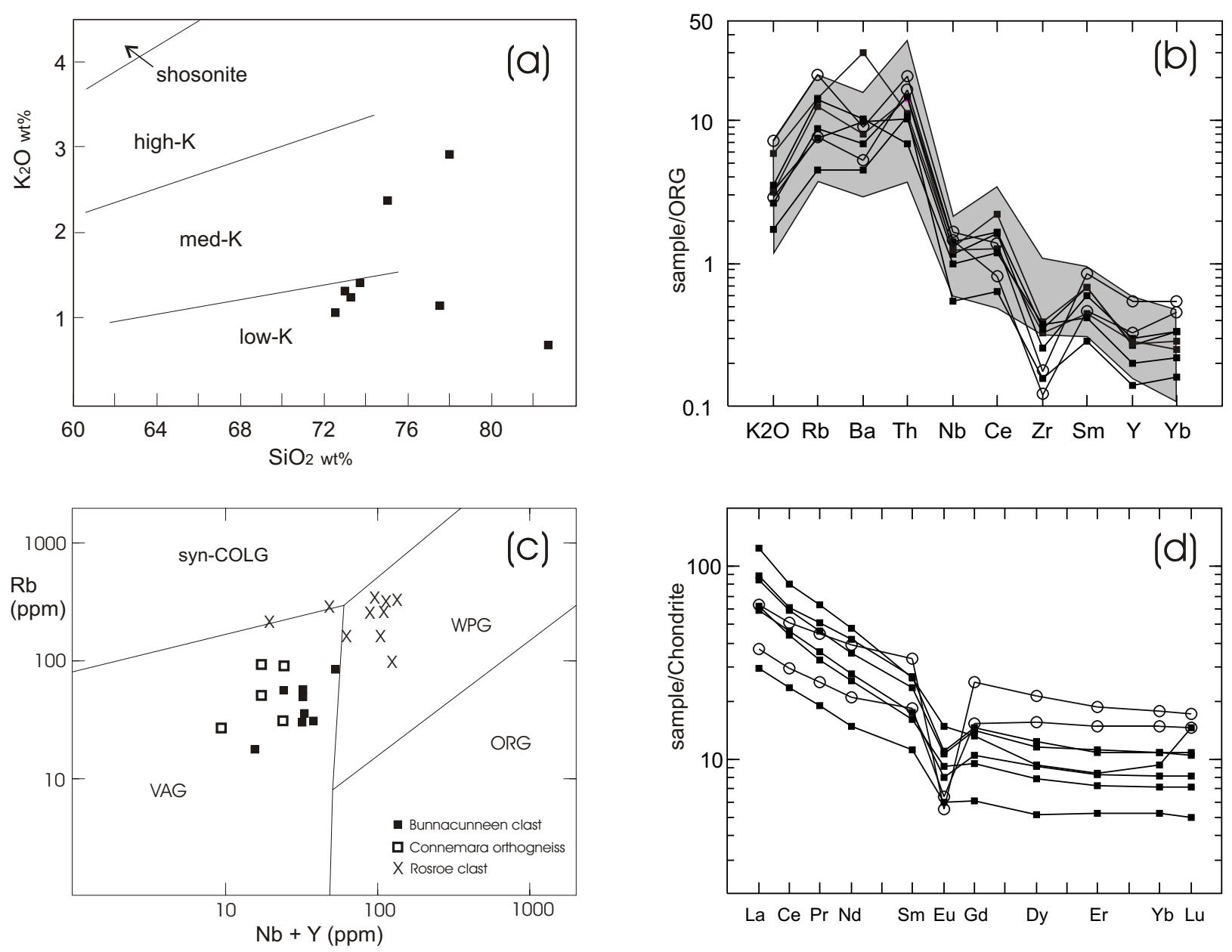


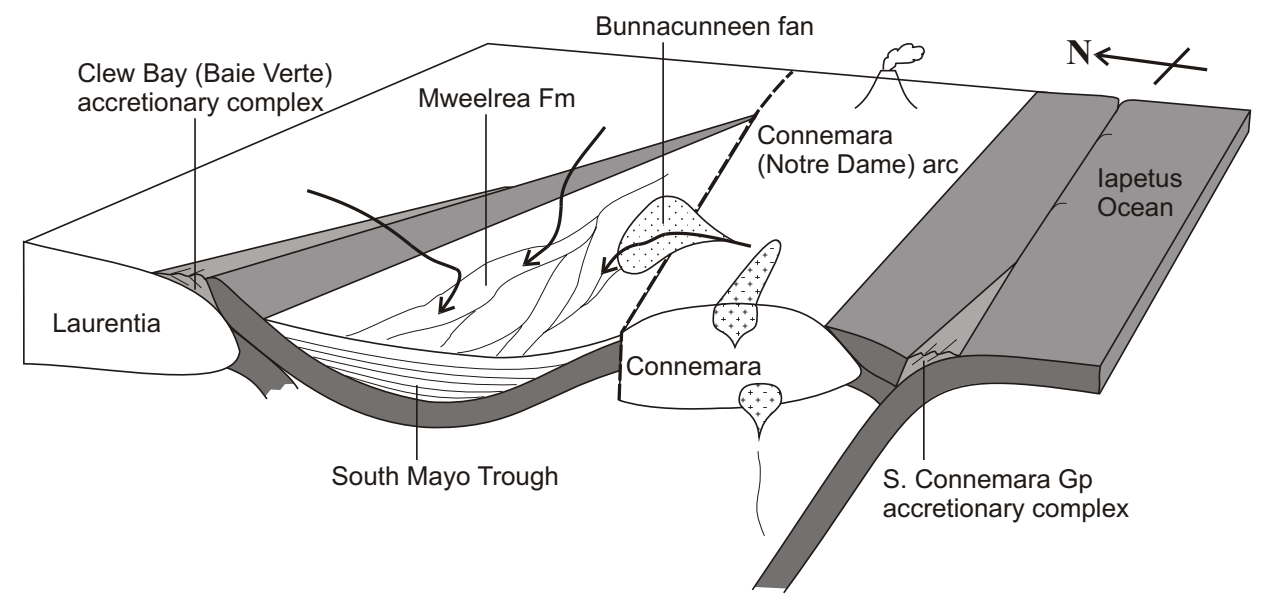

